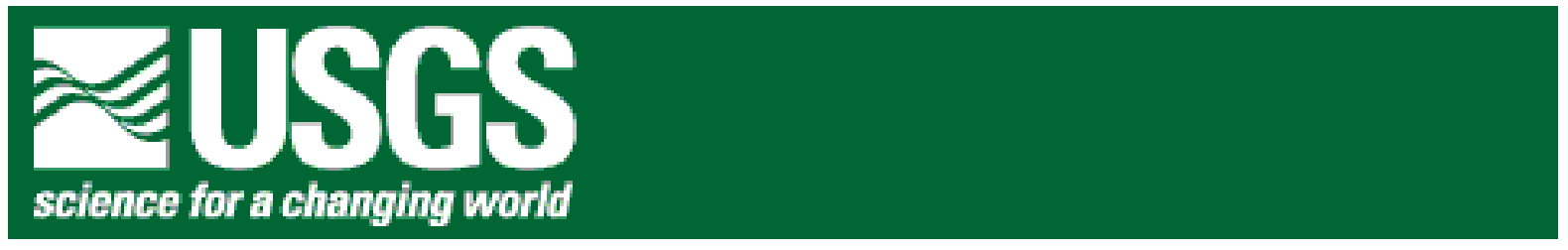

\title{
Analytical Results for Municipal Biosolids Samples from a Monitoring Program Near Deer Trail, Colorado (U.S.A.), 2009
}

By J.G. Crock, D.B. Smith, T.J.B. Yager, C.J. Berry, and M.G. Adams

Open-File Report 2010-1162

U.S. Department of the Interior

U.S. Geological Survey 


\section{U.S. Department of the Interior \\ KEN SALAZAR, Secretary}

\section{U.S. Geological Survey \\ Marcia K. McNutt Director}

U.S. Geological Survey, Reston, Virginia: 2010

For product and ordering information:

World Wide Web: http://www.usgs.gov/pubprod

Telephone: 1-888-ASK-USGS

For more information on the USGS-the Federal source for science about the Earth, its natural and living resources, natural hazards, and the environment: World Wide Web: http://www.usgs.gov

Telephone: 1-888-ASK-USGS

Suggested citation:

Crock, J.G., Smith, D.B., Yager, T.J.B., Berry, C.J., and Adams, M.G., 2010, Analytical results for municipal biosolids samples from a monitoring program near Deer Trail, Colorado (U.S.A.), 2009: U.S. Geological Survey Open-File Report 2010-1162, 23 p.

Any use of trade, product, or firm names is for descriptive purposes only and does not imply endorsement by the U.S. Government.

Although this report is in the public domain, permission must be secured from the individual copyright owners to reproduce any copyrighted material contained within this report. 


\section{Contents}

Abstract

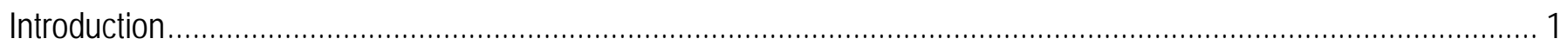

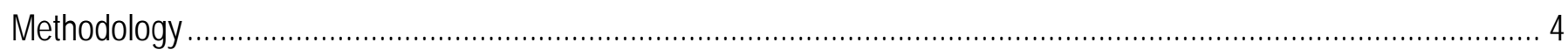

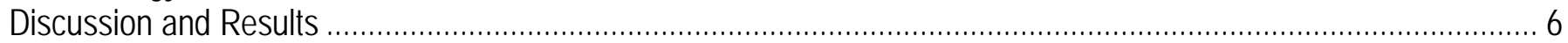

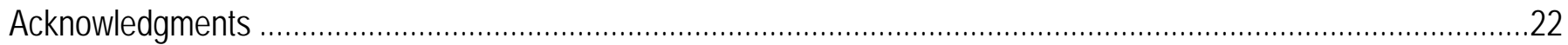

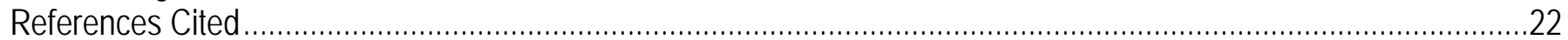

\section{Figures}

1. Map of Metro Wastewater Reclamation District of Denver biosolids-application farm and study area

location

2. Photograph of Biosolids as typically seen after broadcast application to agricultural land ................................ 4

3. Photograph of biosolids sample, as received, prior to drying in the laboratory.............................................. 5

4-13. Graphs showing concentrations of biosolids samples, 1999-2009, of:

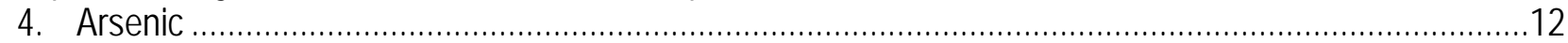

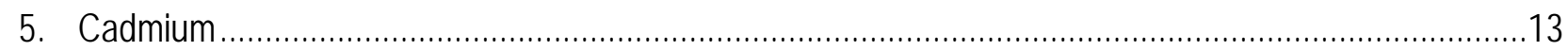

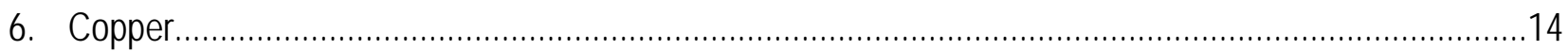

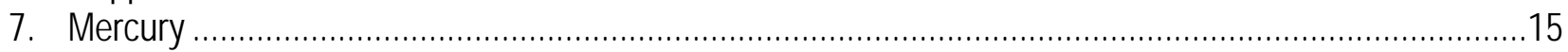

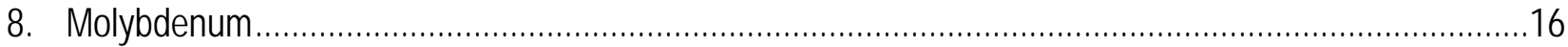

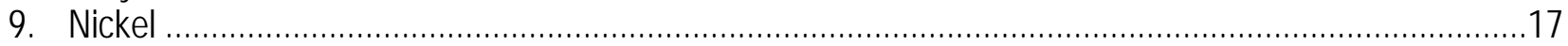

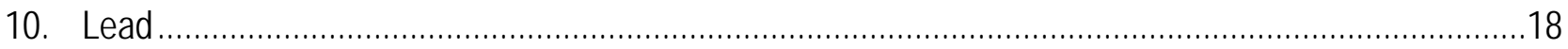

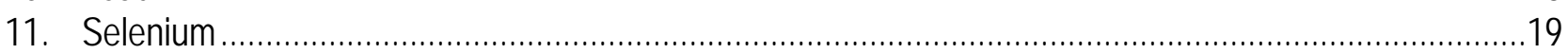

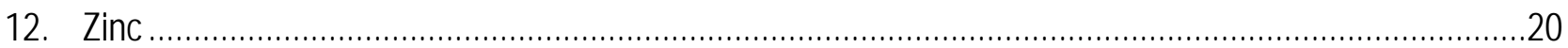

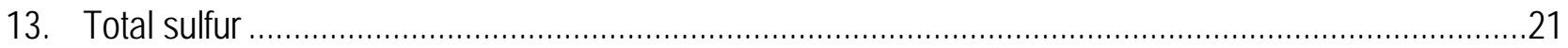

\section{Tables}

1. Priority parameters and analytical methods used for biosolids samples ..................................................... 6

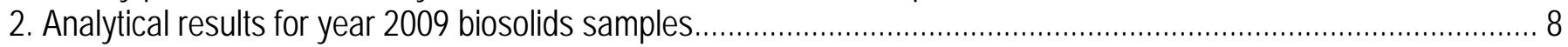




\title{
Analytical Results for Municipal Biosolids Samples from a Monitoring Program Near Deer Trail, Colorado (U.S.A.), 2009
}

\author{
By J.G. Crock, D.B. Smith, T.J.B. Yager, C.J. Berry, and M.G. Adams
}

\begin{abstract}
Since late 1993, Metro Wastewater Reclamation District of Denver, a large wastewater treatment plant in Denver, Colo., has applied Grade I, Class B biosolids to about 52,000 acres of nonirrigated farmland and rangeland near Deer Trail, Colo., U.S.A. In cooperation with the Metro District in 1993, the U.S. Geological Survey began monitoring groundwater at part of this site. In 1999, the Survey began a more comprehensive monitoring study of the entire site to address stakeholder concerns about the potential chemical effects of biosolids applications to water, soil, and vegetation. This more comprehensive monitoring program has recently been extended through the end of 2010. Monitoring components of the more comprehensive study include biosolids collected at the wastewater treatment plant, soil, crops, dust, alluvial and bedrock groundwater, and stream-bed sediment. Streams at the site are dry most of the year, so samples of stream-bed sediment deposited after rain were used to indicate surface-water effects. This report presents analytical results for the biosolids samples collected at the Metro District wastewater treatment plant in Denver and analyzed for 2009.

In general, the objective of each component of the study was to determine whether concentrations of nine trace elements ("priority analytes") (1) were higher than regulatory limits, (2) were increasing with time, or (3) were significantly higher in biosolids-applied areas than in a similar farmed area where biosolids were not applied.

Previous analytical results indicate that the elemental composition of biosolids from the Denver plant was consistent during 1999-2008, and this consistency continues with the samples for 2009. Total concentrations of regulated trace elements remain consistently lower than the regulatory limits for the entire monitoring period. Concentrations of none of the priority analytes appear to have increased during the 11 years of this study.
\end{abstract}

\section{Introduction}

Since 1993, the Metro Wastewater Reclamation District of Denver (Metro District) has been applying biosolids from the Denver metropolitan area to its property near Deer Trail, Colo. (fig.1), as an agricultural soil amendment. The biosolids are applied to nonirrigated farmland according to agronomic loading rates. More information about the sewage-treatment process that produces the Metro District biosolids can be found at http://www.metrowastewater.com (last visited May 12, 2010). The biosolids-application areas, dates of application, and application rates provided by the Metro District for its properties near Deer Trail for 1999 through 2003 are detailed in Stevens and others (2003) and Yager and others (2004a,b,c, 2009). As more information becomes available, it will be posted at the U.S. Geological Survey (USGS) project web page at http://co.water.usgs.gov/projects/CO406/CO406.html (last visited May 12, 2010). 


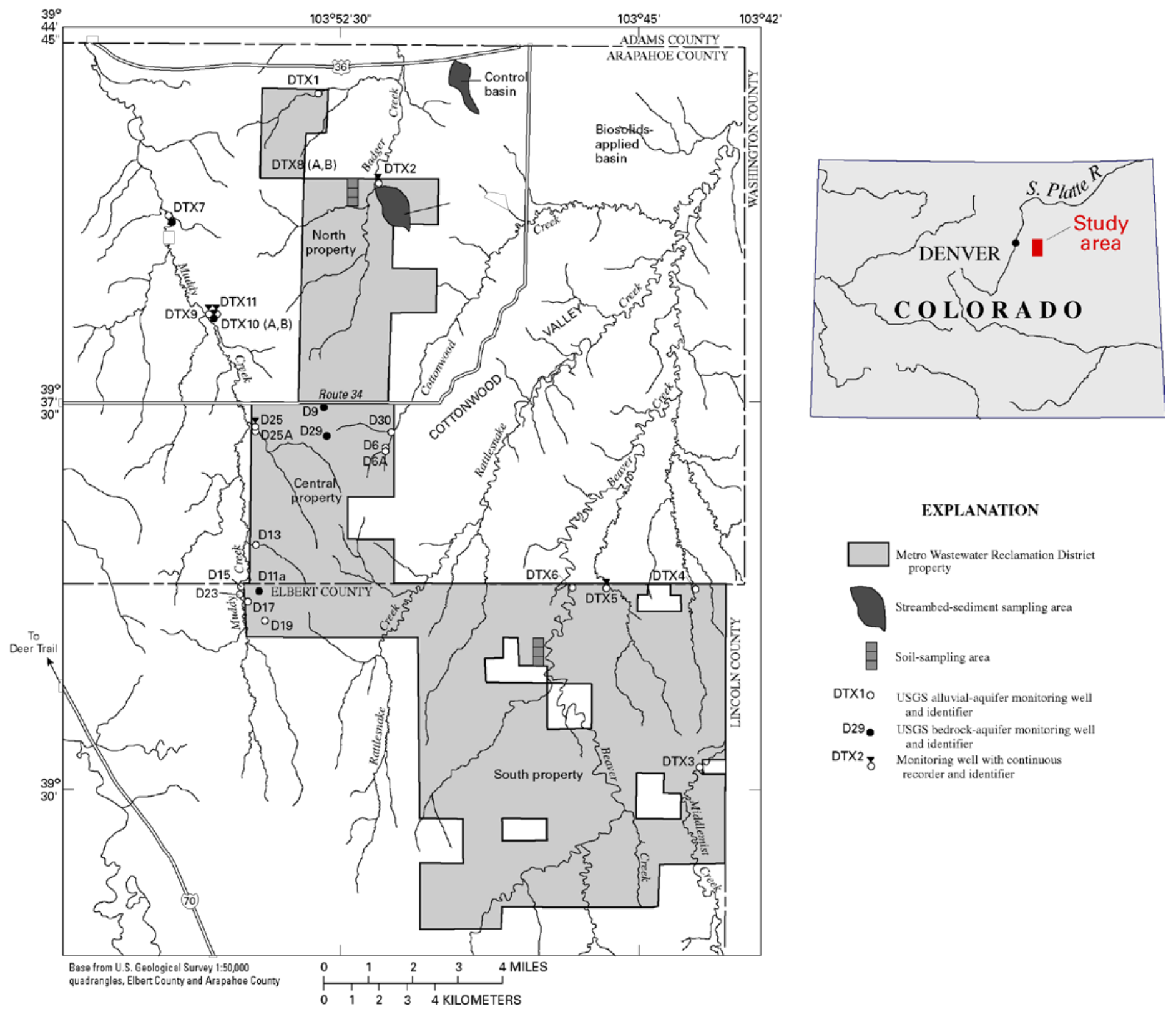

Figure 1. Metro Wastewater Reclamation District of Denver (Metro District) biosolids-application farm and study area location. 
Crock and others (2008a) have presented earlier a compilation of analytical results for the biosolids samples collected and analyzed for 1999 thru 2006, and in a separate report (Crock and others, 2008b), data for the 2007 biosolids are reported and data for the 2008 biosolids samples are presented in Crock and others (2009). More information about the other monitoring components is presented elsewhere in the literature (for example, Yager and others, 2004a,b,c,d, 2009). Priority parameters for biosolids identified by the stakeholders and also regulated by the state of Colorado when used as an agricultural soil amendment include the total concentrations of nine trace elements (arsenic, cadmium, copper, lead, mercury, molybdenum, nickel, selenium, and zinc), plutonium isotopes, and gross alpha and beta activity. Nitrogen and chromium also were priority parameters for groundwater and sediment components. Total sulfur was added as an element of concern in the fall of 2001 and continues to be determined and monitored.

Data from the previous reports (Crock and others, 2008a,b, 2009) and this report were used to compile an inorganic-chemical biosolids signature that can be contrasted with the geochemical signature for this site. The biosolids signature and an understanding of the geology and hydrology of the site can be used to separate biosolids effects from natural geochemical effects. Elements of particular interest for a biosolids signature include bismuth, copper, silver, mercury, and phosphorus.

In 1999, the Metro District property, known as the METROGRO Farm, encompassed about 81 $\mathrm{mi}^{2}$ (52,000 acres) of farmland in Arapahoe and Elbert Counties, Colo. The Metro District property and surrounding private property are herein referred to as "the study area."

Soils in the study area generally are sandy or loamy on flood plains and stream terraces, clayey to loamy on gently sloping to rolling uplands, and sandy and shaley on steeper uplands. About one-half of the Metro District property is farmed; the remaining is rangeland with some pasture. Land use within the rest of the study area during 1993 through 2009 mostly was rangeland or pasture with some cropland. Farmland in the study area was not irrigated. Biosolids were applied to the land surface of the Metro District property as an agricultural soil amendment, and the primary crop was wheat. Figure 2 shows a typical example of what fresh biosolids (the darker colored patches indicated by the white arrows) look like on an agricultural field after a single broadcast application. 


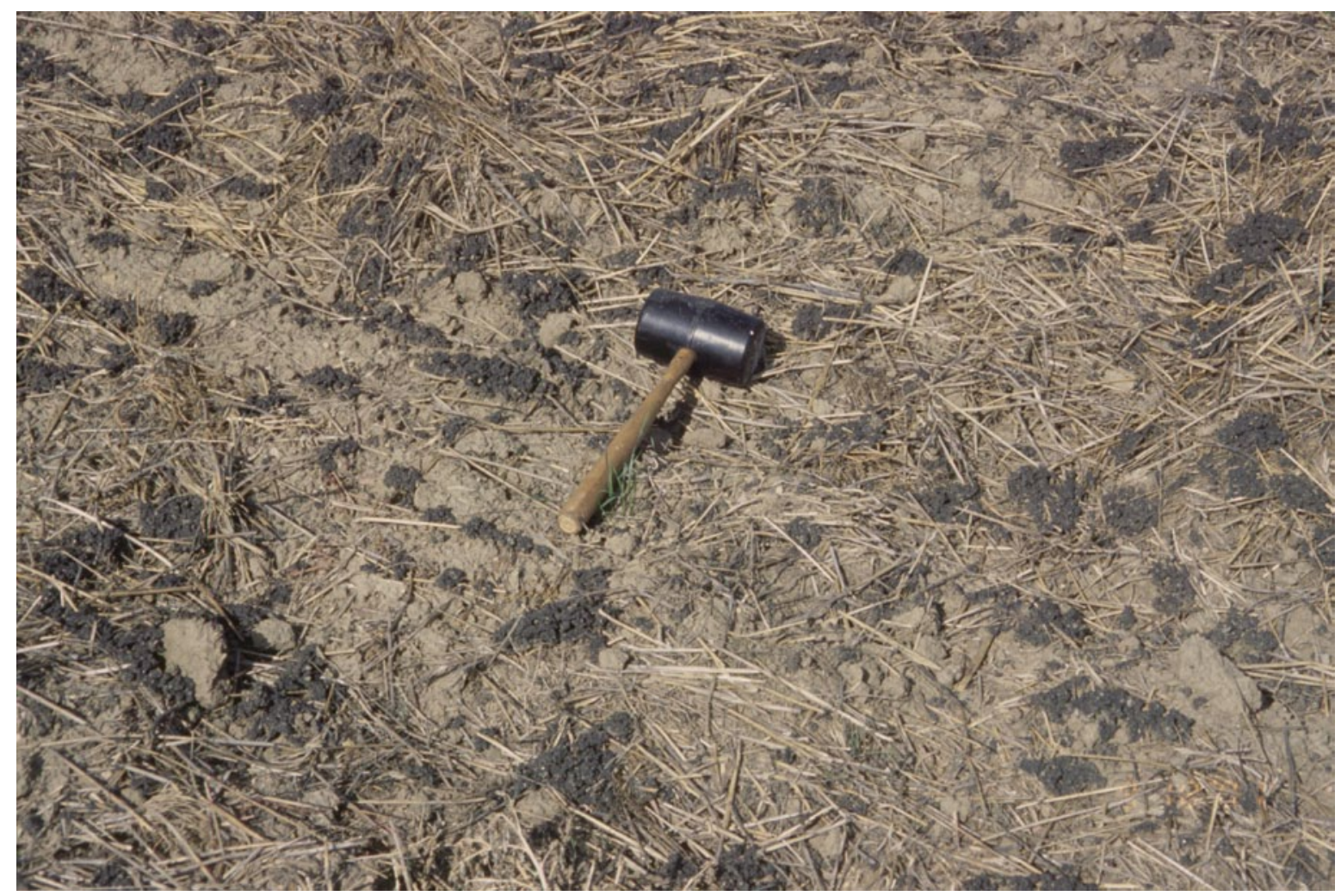

Figure 2. Biosolids as typically seen after broadcast application to agricultural land.

Public concern about applications of biosolids to farmland increased after the Metro District agreed to accept treated groundwater from the Lowry Landfill Superfund site in Denver. The USGS, in cooperation with the Metro District and (in 1999) the North Kiowa Bijou Groundwater Management District, studied natural geochemical conditions and the effects of biosolids applications to the Metro District properties near Deer Trail, Colo., during 1999 through 2009. The study addressed the concerns about biosolids applications and other farming-related effects on the environment. The objectives of this USGS study were to (1) evaluate the combined effects of biosolids applications, land use, and natural processes on soil, crops, bedrock aquifer, alluvial aquifers, and stream-bed sediments by comparing chemical data to regulatory standards, data from a site where biosolids have not been applied (a control site), or earlier data from the same site (trends); (2) monitor biosolids for trace elements and radioactivity and compare trace-element concentrations and radioactivity with regulatory standards; and (3) characterize the hydrology of the study area. This report provides the 2009 analytical data for biosolids only. Analytical results for biosolids collected between 1999 and 2008 can be found in Crock and others (2008a,b, 2009). A complete discussion of findings for all matrices and the other study area objectives is detailed in Yager and others (2004d, 2009).

\section{Methodology}

Biosolids are solid organic matter recovered from a sewage-treatment process that meets State and Federal regulatory criteria for beneficial use, such as for a soil amendment. Figure 3 shows freshly collected biosolids from the Metro District plant spread out in a plastic-lined box to dry. 


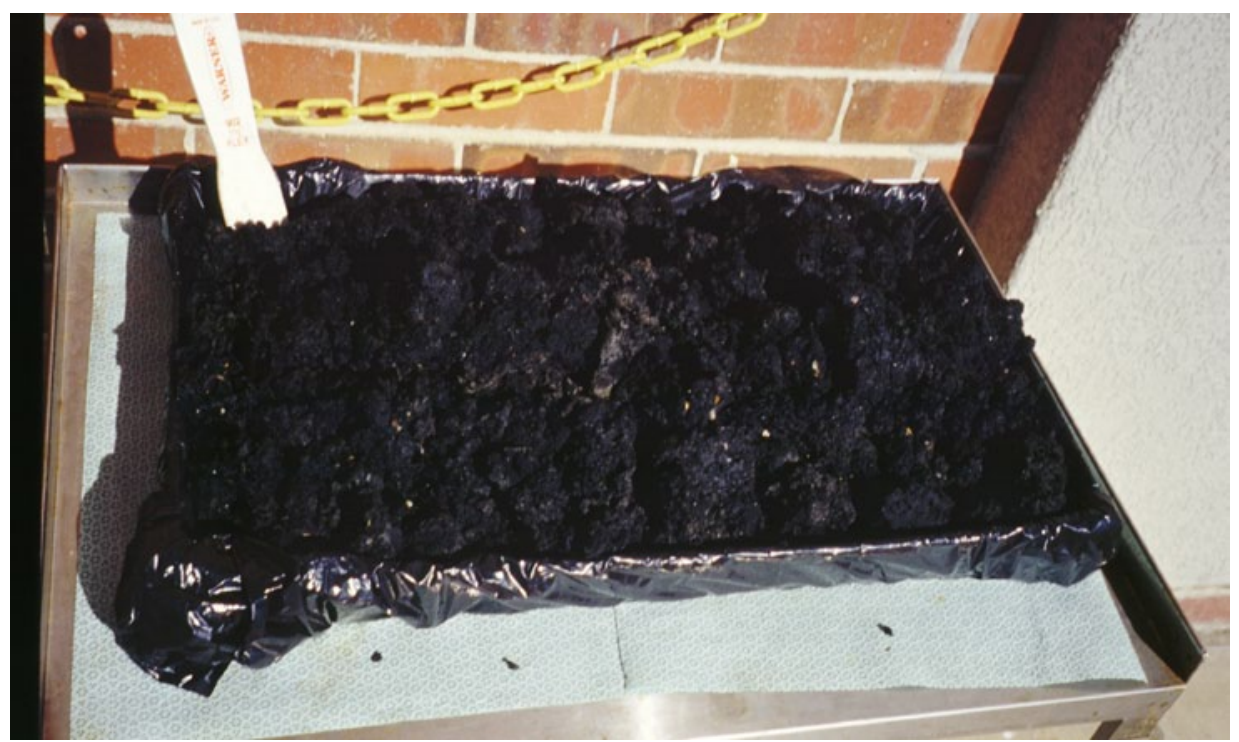

Figure 3. Biosolids sample, as received, prior to drying in the laboratory.

Biosolids are moist (usually ranging 75-85 percent moisture) and have a firm, pudding-like texture. The regulations state that land-applied biosolids must meet or exceed “Table 1” Ceiling Concentration Limits and Class B pathogen criteria (Grade II, Class B criteria in the Colorado regulations until 2003) (U.S. Environmental Protection Agency, 1993; Colorado Department of Public Health and Environment, 1998). Table 3 and Grade I requirements are stricter than Table 1 and Grade II requirements. The Metro District applies Table 3 (Grade I) Class B biosolids to their properties near Deer Trail. The regulatory references for biosolids can be found at the following websites (all last visited May 12, 2010):

http://www.cdphe.state.co.us/wq/PermitsUnit/biosolids/index.html http://www.epa.gov/owm/mtb/biosolids/503pe/index.htm http://www.epa.gov/owm/mtb/biosolids/index.htm\#awards

The biosolids-application areas, dates of application, and application rates provided by the Metro District for their properties near Deer Trail are detailed in Stevens and others (2003) and Yager and others (2004a,b,c, 2009).

Priority parameters identified by stakeholders for biosolids (arsenic, cadmium, copper, lead, mercury, molybdenum, nickel, selenium, and zinc; gross alpha and gross beta radioactivity, and plutonium isotopes; and later in the study, total sulfur) included the nine trace elements regulated by the State of Colorado for biosolids. A random sub-sample from the 2009 samples will be analyzed during 2010 for plutonium isotopes and results will be reported separately. Consult table 1 in this report for a complete list of the priority elements determined by the various analytical methods. Additional elements were determined by the multi-element inductively coupled plasma-mass spectrometry (ICP-MS) method (Briggs and Meier, 1999; Taggart, 2002).

Monthly biosolids samples were collected directly from the Metro District facility's processing line in Denver, rather than from individual trucks or fields near Deer Trail, to ensure a more representative sample. Each biosolids sample was a 24-hour composite consisting of 12 subsamples collected about every 2 hours by Metro District personnel at the Metro District facility. The subsamples were collected from the conveyor belt that transfers the biosolids into the transport trucks. 
The samples were prepared and analyzed at the chemical laboratories of the USGS Crustal Geophysics and Geochemistry Science Center, Denver, Colo. The biosolids material was air dried using forced air and an infrared lamp (surface temperature $\approx 40^{\circ} \mathrm{C}$ ) and then ground in an agate-lined shatter box to less than $150 \mu \mathrm{m}$ prior to chemical analysis. Complete details of the analytical methods and the qualityassurance protocols used are described by Stevens and others (2003), Taggart (2002), and Yager and others (2004a,b,c, 2009). For quality control and quality assurance, the National Institute of Standards and Technology (NIST) standard reference material (SRM) 2781 for domestic sludge was analyzed along with the 2009 biosolids samples.

Table 1. Priority parameters and analytical methods used for biosolids samples.

\begin{tabular}{l|l|l|}
\multicolumn{1}{c}{ Parameter } & \multicolumn{1}{c|}{ Reference } \\
\hline \hline Arsenic & HG-AAS & Hageman and Welsch (1996); Taggart (2002) \\
\hline Cadmium & ICP-MS $^{2}$ & Briggs and Meier (1999); Taggart (2002) \\
\hline Copper & ICP-MS $^{2}$ & Briggs and Meier (1999); Taggart (2002) \\
\hline Lead & ICP-MS $^{2}$ & Briggs and Meier (1999); Taggart (2002) \\
\hline Mercury & CV-AFS $^{3}$ & Hageman (2007) \\
\hline Molybdenum & ICP-MS $^{2}$ & Briggs and Meier (1999); Taggart (2002) \\
\hline Nickel & ICP-MS $^{2}$ & Briggs and Meier (1999); Taggart (2002) \\
\hline Selenium & HG-AAS $^{1}$ & Hageman and Welch (1996); Taggart (2002) \\
\hline Zinc & ICP-MS $^{2}$ & Briggs and Meier (1999); Taggart (2002) \\
\hline Total Sulfur & $\begin{array}{l}\text { Combustion, IR } \\
\text { detection }\end{array}$ & Brown and Curry (2002) \\
\hline
\end{tabular}

${ }^{1}$ Hydride Generation - Atomic Absorption Spectrometry

${ }^{2}$ Inductively Coupled Plasma - Mass

Spectrometry

${ }^{3}$ Continuous Flow - Cold Vapor - Atomic Fluorescence Spectrometry

${ }^{4}$ Automated combustion in oxygen, measured by a solid state infrared detector

\section{Discussion and Results}

Biosolids exceeding the regulatory standards for trace elements could adversely affect the quality of soil on which the biosolids are applied and could alter Metro District plans for the application of biosolids in Arapahoe and Elbert Counties. The composition of biosolids was monitored to provide an independently determined data set against which the Metro District chemical analyses and the regulatory standards for biosolids can be compared. The 2009 data will also augment the chemical baseline that has been established earlier by Crock and others (2008a,b, 2009) against which any future change in the concentration of constituents analyzed for in this study may be identified, 
measured, and compared. This data set will also build on the "geochemical signature" for biosolids that will potentially enable scientists to recognize when biosolids have impacted soils or stream sediments.

All data for the 1999-2008 biosolids samples are presented in Crock and others (2008a,b, 2009) and are presented in figures 4-13 supplemented with the 2009 data presented in this report. The concentrations of all nine trace elements show little variation when plotted throughout the study (1999-2009) and below the Grade 1 biosolids requirements. Analytical results foe reference material NIST SRM 2781 results are also presented in table 2 in this report. The certificate of analysis for NIST SRM 2781 can be found at https://www-s.nist.gov/srmors/view_cert.cfm?srm=2781 (last visited May 12, 2010) 
Table 2. Analytical results for year 2009 biosolids samples.

\begin{tabular}{|c|c|c|c|c|c|c|c|c|c|c|c|c|}
\hline $\begin{array}{l}\text { Sample } \\
\text { Number }\end{array}$ & $\begin{array}{l}\text { ICP-MS* } \\
\text { Ag, ppm }\end{array}$ & $\begin{array}{c}\text { ICP-MS } \\
\text { Al, \% }\end{array}$ & $\begin{array}{l}\text { ICP-MS } \\
\text { As, ppm }\end{array}$ & $\begin{array}{l}\text { HG-AAS }^{\#} \\
\text { As, ppm }\end{array}$ & $\begin{array}{l}\text { ICP-MS } \\
\text { Ba, ppm }\end{array}$ & $\begin{array}{l}\text { ICP-MS } \\
\text { Be, ppm }\end{array}$ & $\begin{array}{l}\text { ICP-MS } \\
\text { Bi, ppm }\end{array}$ & $\begin{array}{c}\text { ICP-MS } \\
\text { Ca, \% }\end{array}$ & $\begin{array}{l}\text { ICP-MS } \\
\text { Cd, ppm }\end{array}$ & $\begin{array}{l}\text { ICP-MS } \\
\text { Ce, ppm }\end{array}$ & $\begin{array}{l}\text { ICP-MS } \\
\text { Co, ppm }\end{array}$ & $\begin{array}{l}\text { ICP-MS } \\
\text { Cr, ppm }\end{array}$ \\
\hline Bios 01/09 & 11.4 & 0.97 & 1.5 & 1.34 & 339 & 0.44 & 2.59 & 3.27 & 1.9 & 18.6 & 2.6 & 32.3 \\
\hline Bios 02/09 & 10.6 & 1.04 & 1.4 & 1.17 & 363 & 0.19 & 2.58 & 2.91 & 1.9 & 25.0 & 3.0 & 32.4 \\
\hline Bios 03/09 & 11.6 & 1.06 & 1.7 & 1.31 & 374 & 0.52 & 2.52 & 3.05 & 2.0 & 31.6 & 2.9 & 33.3 \\
\hline Bios 04Av09 & 11.0 & 1.00 & 1.6 & 1.66 & 357 & 0.29 & 2.40 & 2.90 & 1.7 & 21.7 & 2.8 & 31.9 \\
\hline Bios 04B/09 & 11.3 & 0.99 & 1.7 & 1.36 & 368 & 0.46 & 2.40 & 2.91 & 1.6 & 21.2 & 2.8 & 32.5 \\
\hline Bios 04C/09 & 11.1 & 0.95 & 1.3 & 1.39 & 357 & 0.40 & 2.38 & 2.83 & 1.7 & 20.9 & 2.8 & 31.7 \\
\hline Bios 05/09 & 11.0 & 1.13 & 1.8 & 1.63 & 327 & 0.26 & 2.27 & 2.97 & 1.5 & 22.8 & 3.2 & 33.4 \\
\hline Bios 06/09 & 11.5 & 1.25 & 2.7 & 1.68 & 350 & 0.24 & 2.42 & 3.10 & 1.7 & 28.6 & 3.2 & 34.4 \\
\hline Bios 07/09 & 11.0 & 1.29 & 2.5 & 1.89 & 355 & 0.31 & 2.36 & 3.15 & 2.0 & 32.4 & 3.2 & 39.6 \\
\hline Bios 08A/09 & 9.6 & 1.24 & 2.5 & 1.89 & 375 & 0.26 & 2.68 & 3.14 & 2.8 & 29.0 & 3.5 & 32.7 \\
\hline Bios 08B/09 & 9.6 & 1.25 & 2.8 & 1.92 & 377 & 0.32 & 2.83 & 3.09 & 2.8 & 30.6 & 3.4 & 39.0 \\
\hline Bios 08C/09 & 9.6 & 1.22 & 2.9 & 1.82 & 379 & 0.18 & 2.76 & 3.08 & 2.8 & 31.5 & 3.4 & 36.0 \\
\hline Bios 09/09 & 9.6 & 1.14 & 2.4 & 1.86 & 380 & 0.29 & 2.58 & 3.15 & 3.1 & 27.2 & 3.2 & 33.7 \\
\hline Bios 10/09 & 9.6 & 1.08 & 2.1 & 1.58 & 376 & $<0.03$ & 2.40 & 3.06 & 3.0 & 23.5 & 3.0 & 32.7 \\
\hline Bios 11/09 & 9.6 & 1.00 & 2.0 & 1.42 & 346 & 0.30 & 2.34 & 2.90 & 2.7 & 24.3 & 2.9 & 31.3 \\
\hline Bios 12/09 & 9.6 & 0.91 & 1.8 & 1.42 & 330 & 0.20 & 2.38 & 3.24 & 2.2 & 21.8 & 3.2 & 34.2 \\
\hline $\begin{array}{l}\text { NIST } 2781 \\
\text { NIST } 2781\end{array}$ & 9.6 & 1.38 & 7.9 & 5.47 & 618 & 0.38 & 4.73 & 3.60 & 12.0 & 82.2 & 5.8 & 163 \\
\hline $\begin{array}{l}\text { Recommended/ } \\
\text { Certified Value }\end{array}$ & 9.6 & $1.6 \pm 0.1$ & $7.82 \pm 0.28$ & $7.82 \pm 0.28$ & & & & $3.9 \pm 0.1$ & $12.78 \pm 0.72$ & & & $202 \pm 9$ \\
\hline
\end{tabular}


Table 2. Analytical results for year 2009 biosolids samples.--Continued

\begin{tabular}{|c|c|c|c|c|c|c|c|c|c|c|c|c|}
\hline $\begin{array}{l}\text { Sample } \\
\text { Number }\end{array}$ & $\begin{array}{l}\text { ICP-MS } \\
\text { Cs, ppm }\end{array}$ & $\begin{array}{l}\text { ICP-MS } \\
\text { Cu, ppm }\end{array}$ & $\begin{array}{l}\text { ICP-MS } \\
\text { Fe, \% }\end{array}$ & $\begin{array}{l}\text { ICP-MS } \\
\text { Ga, ppm }\end{array}$ & $\begin{array}{l}\text { CV-AFS }{ }^{\star \star} \\
\mathrm{Hg}, \mathrm{ppm}\end{array}$ & $\begin{array}{c}\text { ICP-MS } \\
\mathrm{K}, \% \\
\end{array}$ & $\begin{array}{l}\text { ICP-MS } \\
\text { La, ppm }\end{array}$ & $\begin{array}{l}\text { ICP-MS } \\
\text { Li, ppm }\end{array}$ & $\begin{array}{l}\text { ICP-MS } \\
\mathrm{Mg}, \%\end{array}$ & $\begin{array}{l}\text { ICP-MS } \\
\text { Mn, ppm }\end{array}$ & $\begin{array}{l}\text { ICP-MS } \\
\text { Mo, ppm }\end{array}$ & $\begin{array}{c}\text { ICP-MS } \\
\mathrm{Na}, \%\end{array}$ \\
\hline Bios 01/09 & 0.32 & 630 & 1.28 & 3.1 & 1.05 & 0.219 & 14.2 & 2.6 & 0.374 & 191 & 22.0 & 0.110 \\
\hline Bios 02/09 & 0.38 & 634 & 1.51 & 2.6 & 1.73 & 0.264 & 19.3 & 4.4 & 0.38 & 179 & 22.0 & 0.135 \\
\hline Bios 03/09 & 0.37 & 665 & 1.55 & 2.6 & 1.56 & 0.263 & 23.8 & 4.2 & 0.391 & 176 & 21.4 & 0.133 \\
\hline Bios 04Av09 & 0.36 & 630 & 1.47 & 3.1 & 1.86 & 0.243 & 16.2 & 3.3 & 0.347 & 192 & 18.7 & 0.119 \\
\hline Bios 04B/09 & 0.37 & 631 & 1.48 & 3.0 & 1.66 & 0.237 & 16.1 & 4.4 & 0.338 & 193 & 19.6 & 0.117 \\
\hline Bios 04C/09 & 0.39 & 610 & 1.44 & 3.0 & 1.39 & 0.235 & 16.2 & 4.2 & 0.326 & 187 & 18.6 & 0.116 \\
\hline Bios 05/09 & 0.42 & 647 & 1.58 & 3.4 & 1.42 & 0.286 & 18.5 & 3.9 & 0.35 & 241 & 18.6 & 0.132 \\
\hline Bios 06/09 & 0.50 & 694 & 2.03 & 4.0 & 1.09 & 0.318 & 21.4 & 3.6 & 0.363 & 274 & 16.5 & 0.148 \\
\hline Bios 07/09 & 0.55 & 703 & 2.11 & 3.2 & 1.43 & 0.318 & 22.2 & 5.3 & 0.375 & 275 & 16.9 & 0.151 \\
\hline Bios 08Av09 & 0.55 & 698 & 2.44 & 3.1 & 1.40 & 0.310 & 21.4 & 5.1 & 0.398 & 523 & 20.2 & 0.145 \\
\hline Bios 08B/09 & 0.55 & 704 & 2.46 & 3.1 & 1.56 & 0.308 & 22.6 & 3.9 & 0.388 & 521 & 20.5 & 0.143 \\
\hline Bios 08C/09 & 0.54 & 698 & 2.45 & 3.1 & 1.63 & 0.301 & 22.9 & 4.7 & 0.389 & 531 & 20.5 & 0.143 \\
\hline Bios 09/09 & 0.46 & 686 & 2.23 & 2.8 & 1.47 & 0.262 & 20.7 & 3.7 & 0.356 & 617 & 21.4 & 0.128 \\
\hline Bios 10/09 & 0.41 & 709 & 1.82 & 2.6 & 1.62 & 0.243 & 17.9 & 4.5 & 0.341 & 426 & 21.3 & 0.116 \\
\hline Bios 12/09 & 0.31 & 604 & 1.82 & 2.2 & 1.27 & 0.228 & 16.2 & 2.8 & 0.341 & 219 & 19.7 & 0.114 \\
\hline $\begin{array}{l}\text { NIST } 2781 \\
\text { NIST } 2781\end{array}$ & 0.82 & 578 & 2.74 & 6.4 & 3.78 & 0.436 & 24.1 & 7.2 & 0.507 & 760 & 42.2 & 0.182 \\
\hline $\begin{array}{l}\text { Recommended/ } \\
\text { Certified Value }\end{array}$ & & $627.4 \pm 13.5$ & $2.8 \pm 0.1$ & & $3.64 \pm 0.25$ & $0.49 \pm 0.03$ & & & $0.59 \pm 0.04$ & & $46.7 \pm 3.2$ & $0.21 \pm 0.02$ \\
\hline
\end{tabular}


Table 2. Analytical results for year 2009 biosolids samples.--Continued

\begin{tabular}{|c|c|c|c|c|c|c|c|c|c|c|c|c|}
\hline $\begin{array}{l}\text { Sample } \\
\text { Number }\end{array}$ & $\begin{array}{l}\text { ICP-MS } \\
\text { Nb, ppm }\end{array}$ & $\begin{array}{l}\text { ICP-MS } \\
\text { Ni, ppm }\end{array}$ & $\begin{array}{c}\text { ICP-MS } \\
\text { P, \% }\end{array}$ & $\begin{array}{l}\text { ICP-MS } \\
\text { Pb, ppm }\end{array}$ & $\begin{array}{l}\text { ICP-MS } \\
\text { Rb, ppm }\end{array}$ & $\begin{array}{c}\text { Total S, IR } \\
\text { S, } \%\end{array}$ & $\begin{array}{l}\text { ICP-MS } \\
\text { Sb, ppm }\end{array}$ & $\begin{array}{l}\text { ICP-MS } \\
\text { Sc, ppm }\end{array}$ & $\begin{array}{l}\text { HG-AAS }^{\#} \\
\text { Se, ppm }\end{array}$ & $\begin{array}{l}\text { ICP-MS } \\
\text { Sr, ppm }\end{array}$ & $\begin{array}{l}\text { ICP-MS } \\
\text { Th, ppm }\end{array}$ & $\begin{array}{c}\text { ICP-MS } \\
\text { Ti, \% }\end{array}$ \\
\hline Bios 01/09 & 44 & 16.9 & 2.15 & 37.2 & 6.6 & 1.49 & 3.3 & 1.2 & 13.4 & 212 & 1.26 & 0.187 \\
\hline Bios 02/09 & 13 & 16.9 & 2.30 & 45.4 & 8.2 & 1.67 & 2.9 & 1.1 & 14.3 & 220 & 1.32 & 0.228 \\
\hline Bios 03/09 & 9.8 & 73.8 & 2.32 & 43.2 & 8.2 & 1.69 & 2.7 & 1.1 & 13.7 & 229 & 1.47 & 0.262 \\
\hline Bios 04Av09 & 27 & 15.1 & 2.16 & 41.3 & 7.6 & 1.66 & 2.6 & 1.3 & 14.7 & 217 & 1.65 & 0.242 \\
\hline Bios 04B/09 & 28 & 14.6 & 2.15 & 40.7 & 7.6 & 1.67 & 3.2 & 1.3 & 14.5 & 222 & 1.39 & 0.234 \\
\hline Bios 04C/09 & 27 & 14.5 & 2.08 & 42.3 & 7.7 & 1.66 & 2.7 & 1.2 & 14.8 & 220 & 1.34 & 0.232 \\
\hline Bios 05/09 & 24 & 15.4 & 2.09 & 38.9 & 9.0 & 1.67 & 1.9 & 1.4 & 15.5 & 227 & 1.60 & 0.257 \\
\hline Bios 06/09 & 36 & 16.2 & 2.20 & 45.2 & 10.8 & 1.79 & 2.5 & 1.7 & 15.4 & 252 & 1.90 & 0.266 \\
\hline Bios 07/09 & 8.4 & 17.1 & 2.20 & 43.8 & 11.5 & 1.85 & 2.5 & 1.6 & 15.4 & 253 & 1.81 & 0.225 \\
\hline Bios 08AV09 & 5.0 & 18.2 & 2.29 & 59.9 & 11.1 & 1.99 & 2.5 & 1.4 & 15.5 & 243 & 1.68 & 0.218 \\
\hline Bios 08B/09 & 5.4 & 18.2 & 2.30 & 67.6 & 11.2 & 1.97 & 2.5 & 1.4 & 15.4 & 245 & 1.91 & 0.213 \\
\hline Bios 08C/09 & 5.1 & 18.9 & 2.26 & 62.8 & 10.9 & 1.99 & 2.5 & 1.4 & 15.5 & 245 & 1.83 & 0.221 \\
\hline Bios 09/09 & 4.4 & 17.6 & 2.24 & 48.2 & 9.4 & 2.01 & 2.4 & 1.1 & 15.5 & 245 & 2.09 & 0.208 \\
\hline Bios 10/09 & 3.6 & 16.0 & 2.14 & 41.9 & 8.2 & 1.88 & 2.0 & 1.0 & 15.4 & 255 & 1.28 & 0.213 \\
\hline Bios 11/09 & 3.6 & 17.1 & 2.06 & 40.9 & 7.4 & 1.76 & 2.1 & 0.9 & 15.5 & 240 & 1.32 & 0.225 \\
\hline Bios 12/09 & 3.1 & 16.5 & 2.06 & 39.9 & 6.9 & 1.69 & 2.3 & 0.9 & 15.4 & 235 & 1.16 & 0.207 \\
\hline $\begin{array}{l}\text { NIST } 2781 \\
\text { NIST } 2781\end{array}$ & 92 & 73.4 & 2.30 & 176 & 16.4 & 1.59 & 6.4 & 70.6 & 15.3 & 223 & 5.70 & 0.281 \\
\hline $\begin{array}{l}\text { Recommended/ } \\
\text { Certified Value }\end{array}$ & & $80.2 \pm 2.3$ & $2.42 \pm 0.09$ & $202.1 \pm 6.5$ & & & & & $16.0 \pm 1.6$ & & & $0.32 \pm 0.03$ \\
\hline
\end{tabular}


Table 2. Analytical results for year 2009 biosolids samples.--Continued

\begin{tabular}{lccccc}
\hline Sample & ICP-MS & ICP-MS & ICP-MS & ICP-MS & ICP-MS \\
Number & TI, ppm & U, ppm & V, ppm & Y, ppm & Zn, ppm \\
\hline Bios 01/09 & 0.10 & 39.2 & 10.0 & 3.0 & 731 \\
Bios 02/09 & 0.11 & 37.1 & 10.7 & 3.1 & 709 \\
Bios 03/09 & 0.10 & 36.1 & 10.3 & 3.1 & 739 \\
Bios 04A/09 & 0.09 & 37.7 & 10.2 & 3.0 & 734 \\
Bios 04B/09 & 0.09 & 38.1 & 10.6 & 3.0 & 735 \\
Bios 04C/09 & 0.09 & 36.9 & 9.8 & 3.0 & 715 \\
Bios 05/09 & 0.12 & 54.8 & 13.2 & 3.5 & 731 \\
Bios 06/09 & 0.12 & 61.0 & 16.0 & 4.2 & 776 \\
Bios 07/09 & 0.15 & 62.1 & 18.5 & 4.1 & 848 \\
Bios 08A/09 & 0.14 & 55.7 & 16.5 & 4.1 & 876 \\
Bios 08B/09 & 0.14 & 55.9 & 17.4 & 4.4 & 874 \\
Bios 08C/09 & 0.14 & 57.5 & 16.6 & 4.3 & 874 \\
Bios 09/09 & 0.12 & 51.7 & 13.5 & 4.0 & 878 \\
Bios 10/09 & 0.11 & 49.6 & 12.0 & 3.4 & 859 \\
Bios 11/09 & 0.10 & 49.8 & 11.6 & 3.0 & 776 \\
Bios 12/09 & 0.09 & 49.0 & 11.1 & 3.0 & 729 \\
NIST 2781 & 0.26 & 37.5 & 86.2 & 27.4 & 1120 \\
$\quad$ NIST 2781 & & & & & \\
Recommended/ & & & & & $1273 \pm 53$ \\
Certified Value & & & & & \\
\hline
\end{tabular}

* - ICP-MS determination after a total, four acid digestion

** - Cold Vapor - Atomic Fluorescence Spectrometry

\# - Hydride Generation - Atomic Absorption Spectrometry

\#\# - Combustion - IR Detection

ppm - parts per million or $\mathrm{mg} \mathrm{Kg}^{-1}$

$\%$ - per cent

Figures 4-13 show the temporal variation of the priority parameters and total sulfur. Arsenic (fig. 4) showed the most variability with its high and low concentration differing by a factor of 6 . All trace-element concentrations were less than the maximum allowable concentrations established for Table 3 (Grade I) biosolids. (Note that molybdenum does not have a maximum allowable concentration established for Table 3 biosolids. The value used is that for Table 1 biosolids.) 


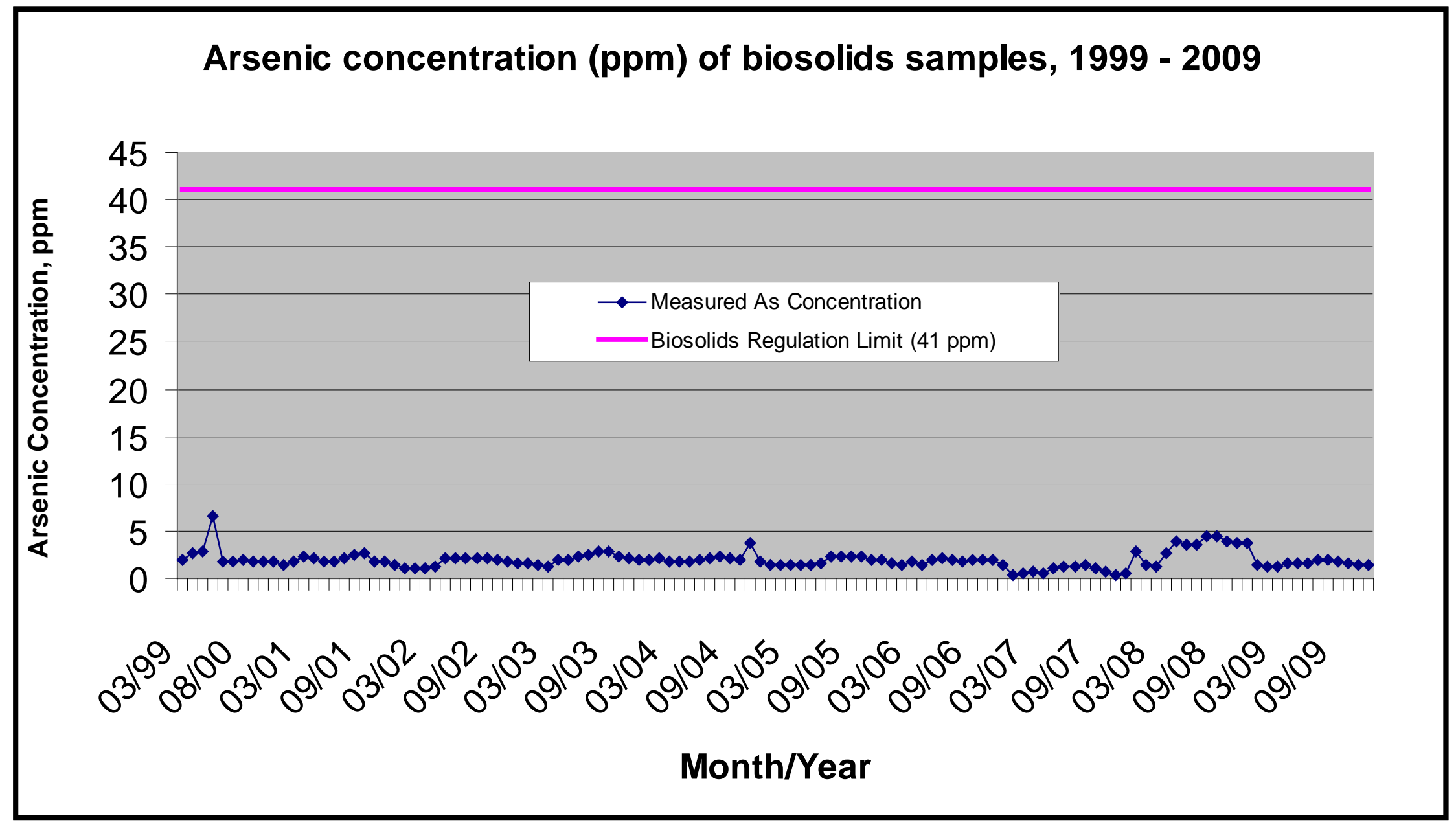

Figure 4. Arsenic concentrations of biosolids samples, 1999-2009. 


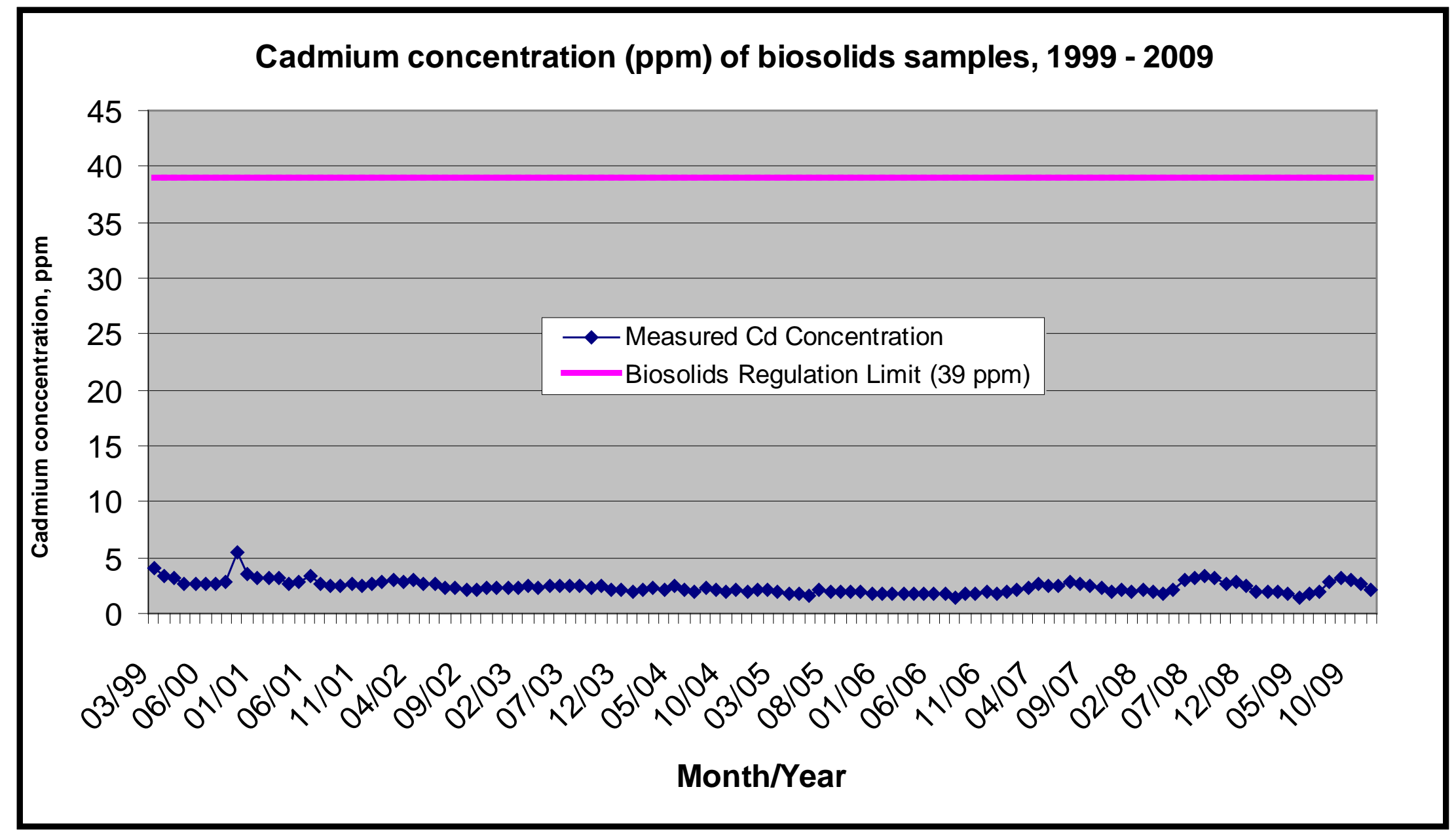

Figure 5. Cadmium concentrations of biosolids samples, 1999-2009. 


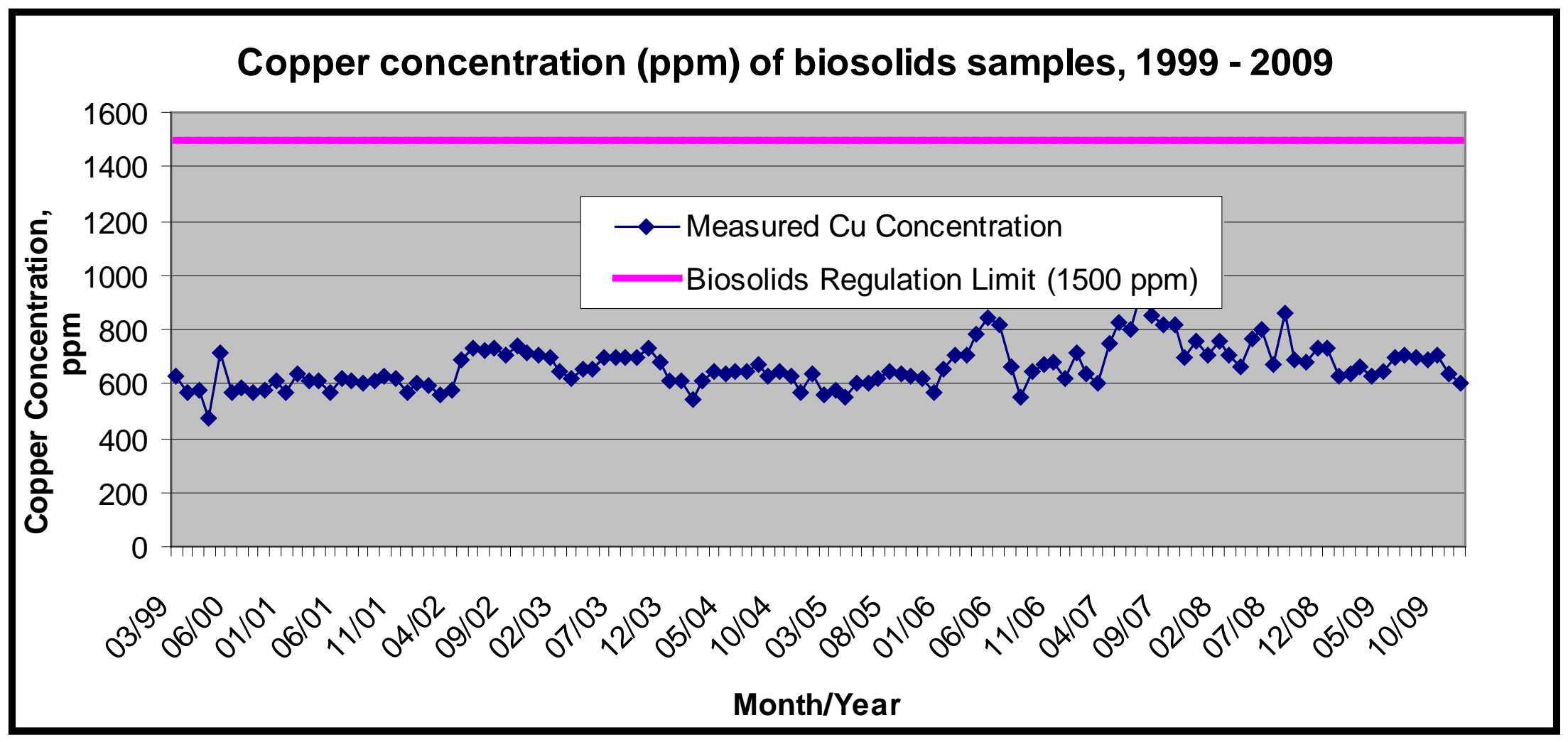

Figure 6. Copper concentrations of biosolids samples, 1999-2009. 


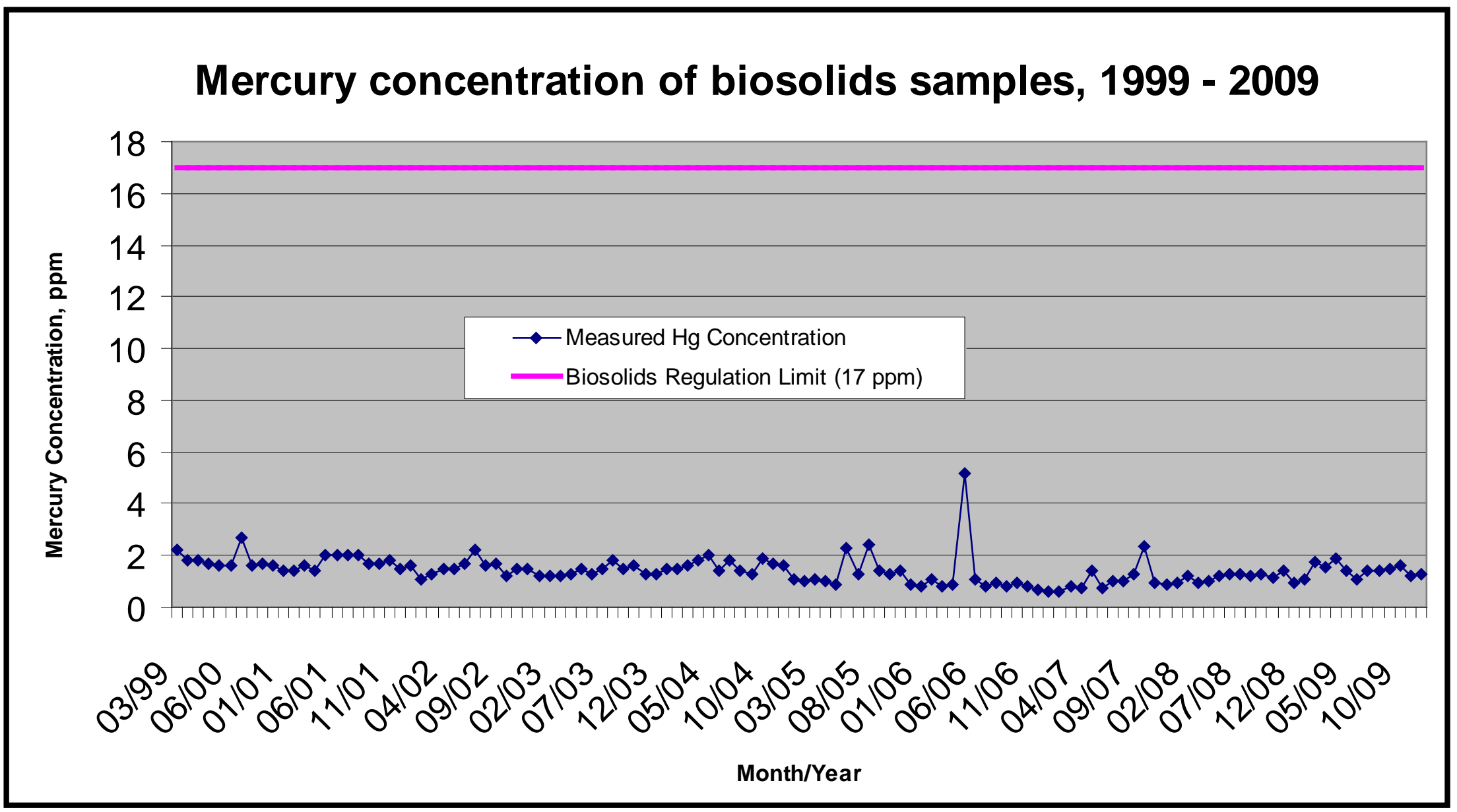

Figure 7. Mercury concentrations of biosolids samples, 1999-2009. 
Molybdenum concentration (ppm) of biosolids samples, 1999 - 2009

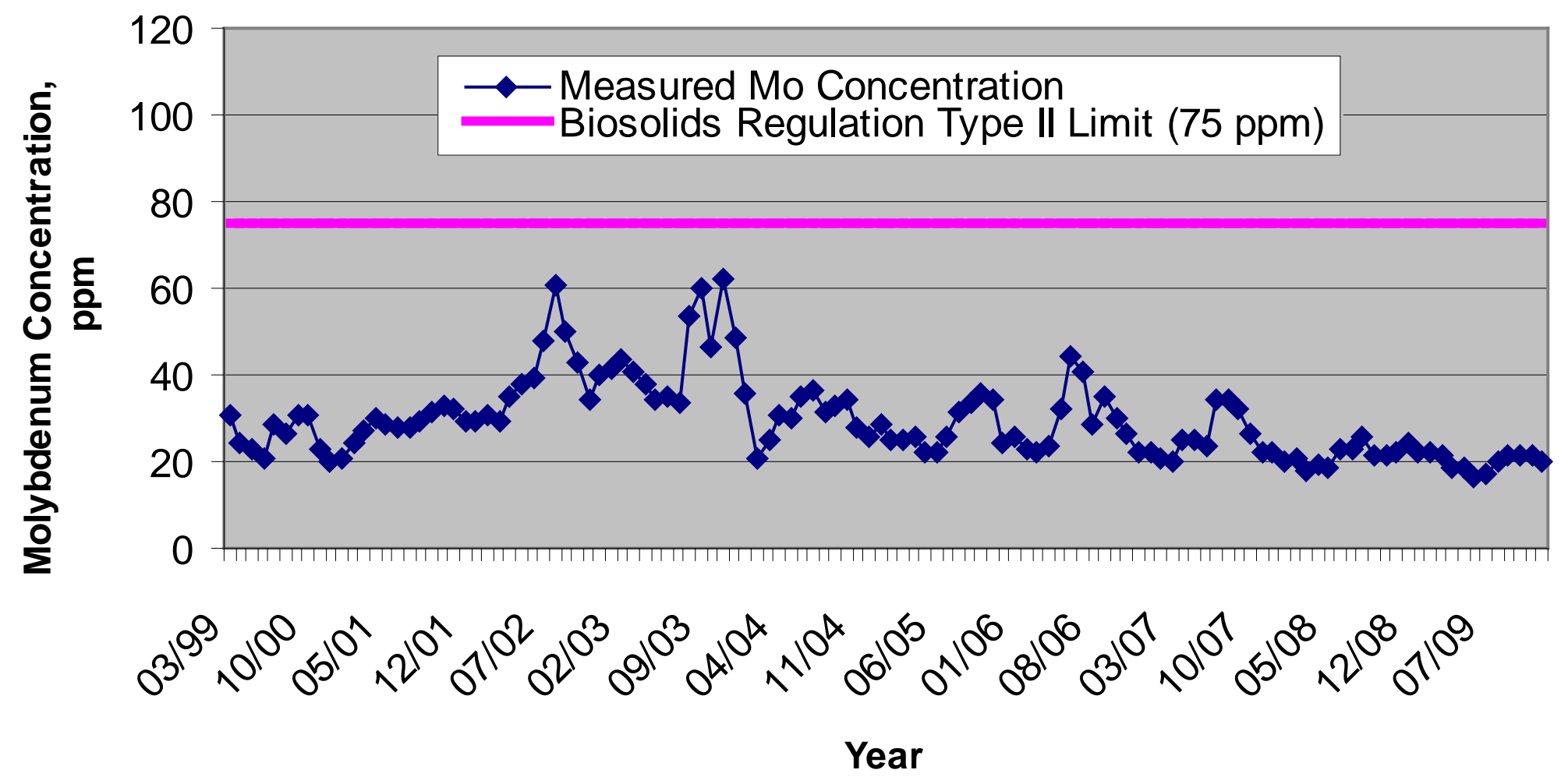

Figure 8. Molybdenum concentrations of biosolids samples, 1999-2009. 


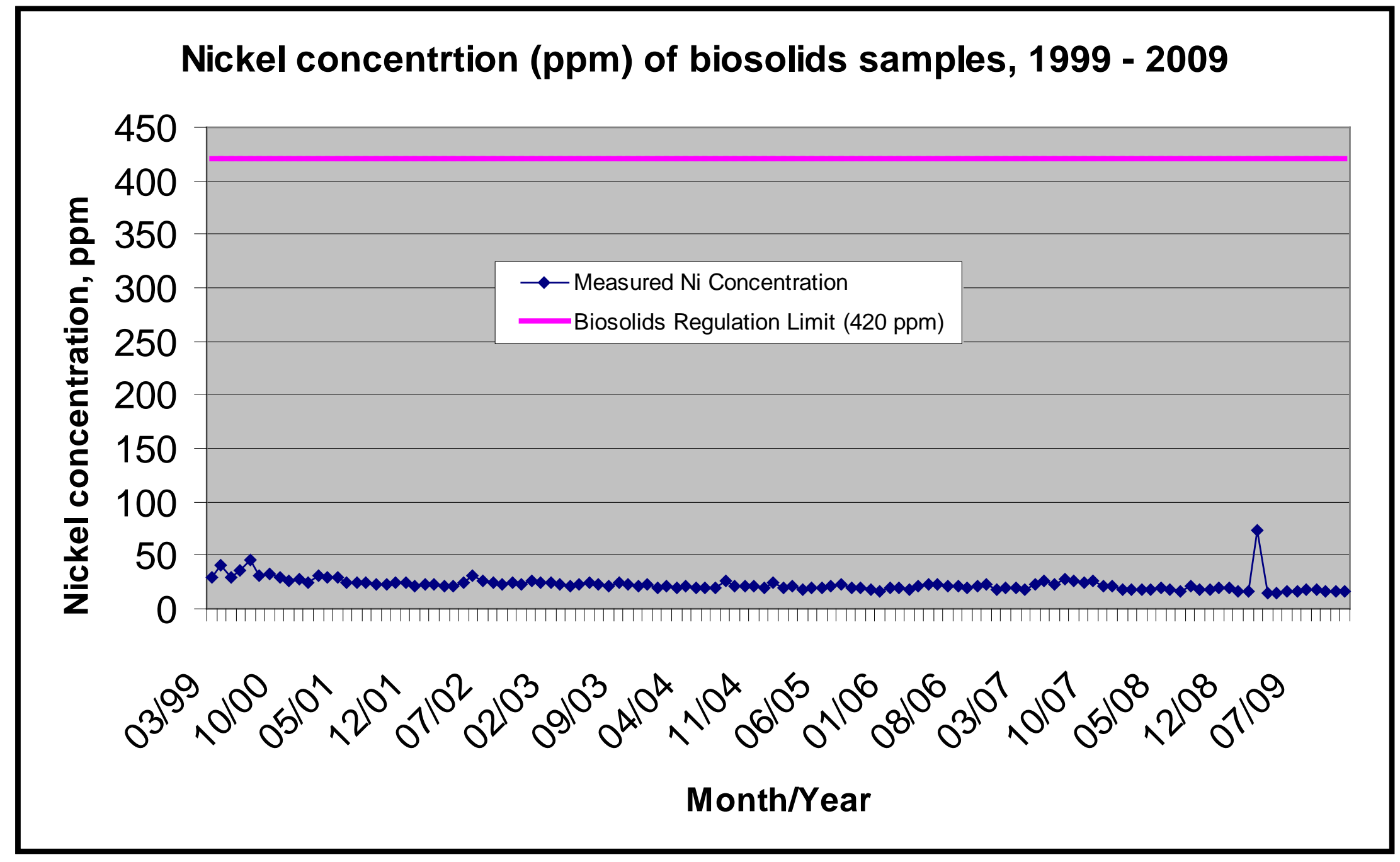

Figure 9. Nickel concentrations of biosolids samples, 1999-2009. 


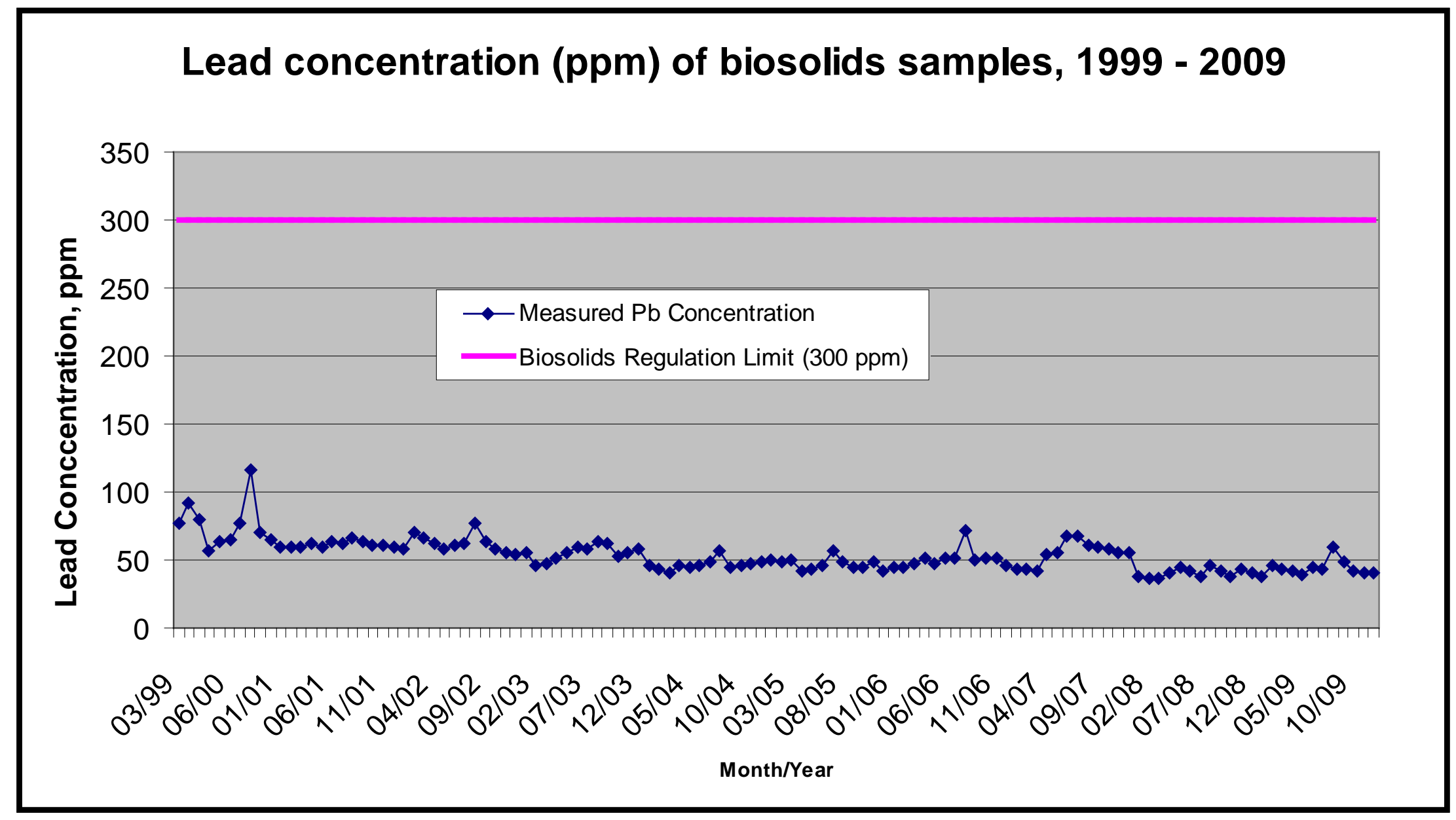

Figure 10. Lead concentrations of biosolids samples, 1999-2009. 


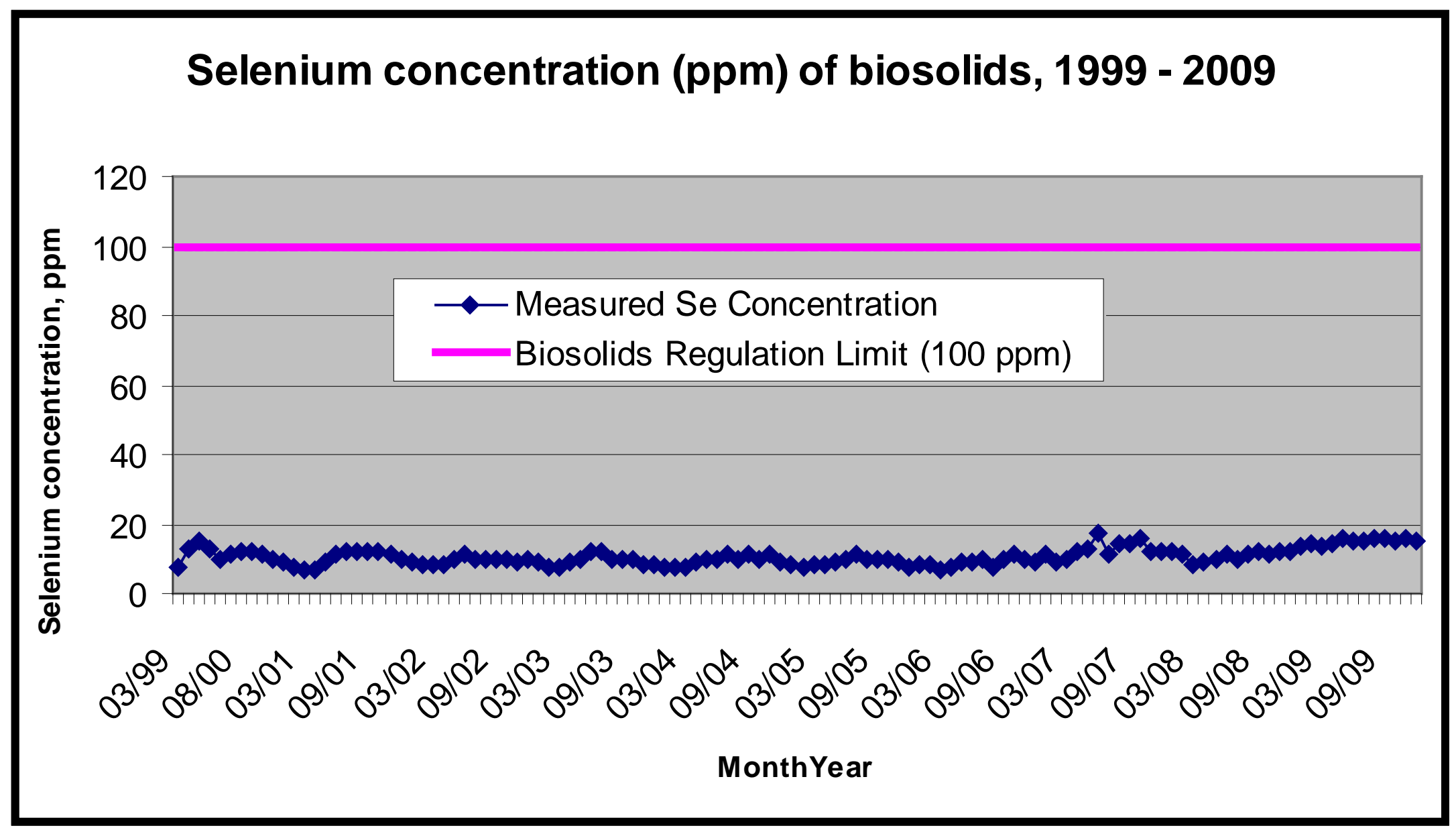

Figure 11. Selenium concentrations of biosolids samples, 1999-2009. 


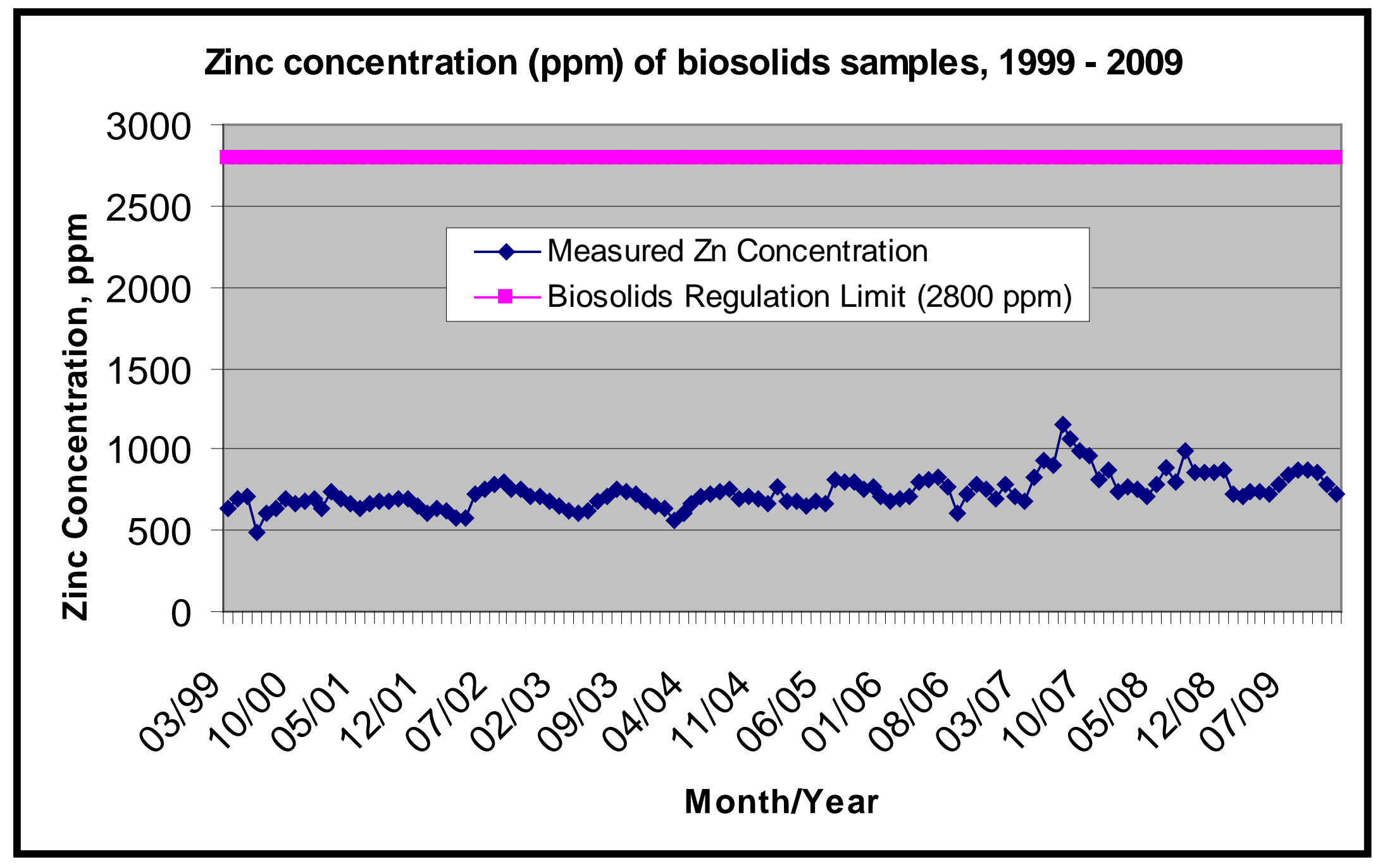

Figure 12. Zinc concentrations of biosolids samples, 1999-2009. 


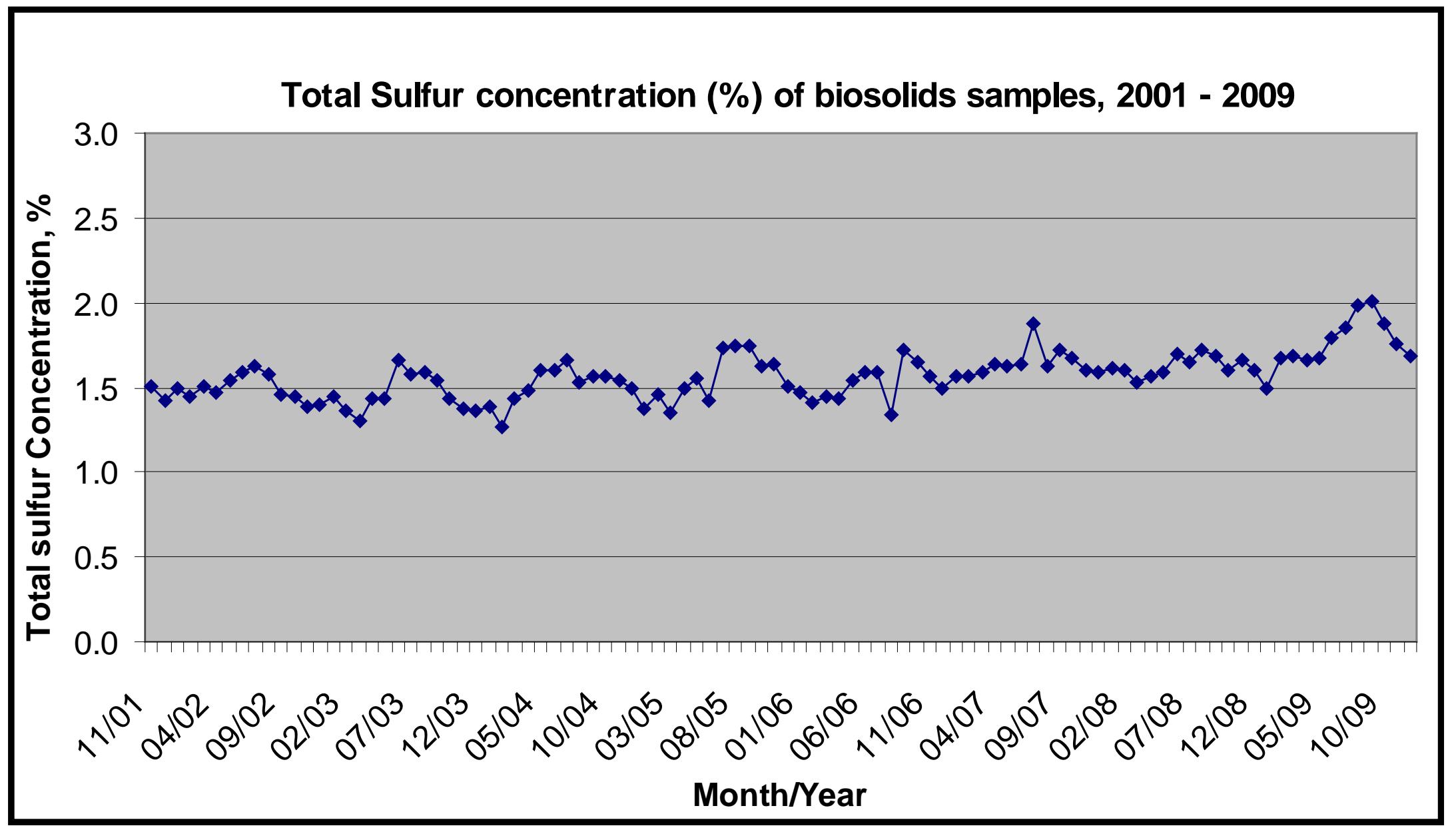

Figure 13. Total sulfur concentration of biosolids samples, 2001-2009. 
In conclusion, chemical data for biosolids samples collected from the Metro District plant during a 11-year period (1999-2009) show that all nine of the trace elements for which regulatory limits are established maintained relatively uniform concentrations and never exceeded the maximum allowable levels for table 3 (Grade I) biosolids.

In addition to the nine trace elements that have regulatory standards established, USGS analyzed the samples for many other elements. Of the regulated elements, mercury and copper had the highest concentrations in biosolids compared to concentrations in soil. Of the nonregulated elements, silver, phosphorous, and bismuth have the highest concentrations in biosolids compared to soils (Yager and others, 2004a,b,c, 2009). Because of their high concentrations in biosolids compared to soils, these five elements would be the most likely "geochemical signature" to indicate that soils or stream sediments may have been impacted by biosolids.

\section{Acknowledgments}

This study was done in cooperation with and funding from the Metro Wastewater Reclamation District and the North Kiowa-Bijou Groundwater Management District, which we thank. The authors also wish to thank Murray Beasley with the analytical chemistry laboratories of the USGS, Denver, for his efforts in the preparation and analyses of the samples for this study and Philip L. Hageman and Paul J. Lamothe, USGS, Denver, for their very helpful review of the manuscript.

\section{References Cited}

Briggs, P.H., and Meier, A.L., 1999, The determination of forty-two elements in geological materials by inductively coupled plasma-mass spectrometry: U.S. Geological Survey Open-File Report 99166, 15 p.

Brown, Z.A., and Curry, K.J., 2002, Total sulfur by combustion, chap. Q, of Taggart, J.E., Jr., ed., Analytical methods for chemical analysis of geological and other materials, U.S. Geological Survey: U.S. Geological Survey Open-File Report 2002-0223, available online at http://pubs.usgs.gov/of/2002/ofr-02-0223/.

Colorado Department of Public Health and Environment, 1998, Biosolids regulation: 5CCR 1002-64, January 12, 1998 (and subsequent revisions), 53 p.

Crock, J.G., Smith, D.B., Yager, T.J.B., Brown, Z.A., and Adams, M.G., 2008a, Analytical results for municipal biosolids samples from a monitoring program near Deer Trail, Colorado (USA), 1999 through 2006: U.S. Geological Survey Open-File Report 2008-1172, 67 p., available online at http://pubs.usgs.gov/of/2008/1172/.

Crock, J.G., Smith, D.B., Yager, T.J.B., Berry, C.J., and Adams, M.G., 2008b, Analytical results for municipal biosolids samples from a monitoring program near Deer Trail, Colorado (U.S.A.), 2007: U.S. Geological Survey Open-File Report 2008-1358, 35 p., available online at http://pubs.usgs.gov/of/2008/1358/.

Crock, J.G., Smith, D.B., Yager, T.J.B., Berry, C.J., and Adams, M.G., 2009, Analytical results for municipal biosolids samples from a monitoring program near Deer Trail, Colorado (USA), 2008: U.S. Geological Survey Open File Report 2009-1090: available online at: http://pubs.usgs.gov/of/2009/1090/, 29 p. 
Hageman, P.L., 2007, TM 5-D2: Determination of mercury in aqueous and geologic materials by continuous flow-cold vapor-atomic fluorescence spectrometry (CVAFS): U.S. Geological Survey Techniques and Methods 5-D2, 6 p., available online at http://pubs.usgs.gov/tm/2007/05D02/.

Hageman, P.L., and Welsch, Eric, 1996, Arsenic, antimony, and selenium by flow injection or continuous flow-hydride generation-atomic absorption spectrometry, in Arbogast, B.F., ed., Analytical methods manual for the Mineral Resource Surveys Program: U. S. Geological Survey Open-File Report 96-525, p. 24-30.

Stevens, M.R., Yager, T.J.B., Smith, D.B., and Crock, J.G., 2003, Biosolids, soils, ground water, and stream bed sediment data for a biosolids-application area near Deer Trail, Colorado: U.S. Geological Survey Open-File Report 02-51, 118 p.

Taggart, J.E., Jr., ed., 2002, Analytical methods for chemical analysis of geological and other materials, U.S. Geological Survey: U.S. Geological Survey Open-File Report 2002-0223, available online at http://pubs.usgs.gov/of/2002/ofr-02-0223/.

U.S. Environmental Protection Agency, 1993, (revised July 1, 2003), Part 503 — Standards for the use or disposal of sewage sludge: Code of Federal Regulations Title 40, v. 27, 40CFR503, p. 820-852.

Yager, T.J.B., and Arnold, L.R., 2003, Hydrogeology of a biosolids-application site near Deer Trail, Colorado, 1993-99: U.S. Geological Survey Water-Resources Investigations Report 03-4209, 90 p.

Yager, T.J.B., Smith, D.B., Crock, J.G., and Stevens, M.R., 2004a, Biosolids, soil, crop, ground water, and stream bed-sediment data for a biosolids-application area near Deer Trail, Colorado, 2000: U.S. Geological Survey Open-File Report 03-400, 90 p.

Yager, T.J.B., Smith, D.B., and Crock, J.G., 2004b, Biosolids, soil, crop, ground water, and stream bed-sediment data for a biosolids-application area near Deer Trail, Colorado, 2001: U.S. Geological Survey Open-File Report 2004-1388, 69 p.

Yager, T.J.B., Smith, D.B., and Crock, J.G., 2004c, Biosolids, soil, crop, ground water, and stream bed-sediment data for a biosolids-application area near Deer Trail, Colorado, 2002-2003: U.S. Geological Survey Open-File Report 2004-1404, 90 p.

Yager, T.J.B., Smith, D.B., and Crock, J.G., 2004d, Effects of surface applications of biosolids on soil, crops, ground water, and stream bed sediment near Deer Trail, Colorado, 1999-2003: U.S. Geological Survey Scientific Investigations Report 2004-5289, 93 p.

Yager, T.J.B., Smith, D.B., and Crock, J.G., 2009, Biosolids, crop, and ground-water data for a biosolids-application area near Deer Trail, Colorado, 2004 through 2006: U.S. Geological Survey Digital Data Series 379, 57 p., available online at: http://pubs.usgs.gov/ds/379/. 